\title{
RADIOCARBON DATING OF KOHITSUGIRE CALLIGRAPHIES ATTRIBUTED TO ASUKAI MASATSUNE AND THE PERIODS OF ORIGIN OF GENJI MONOGATARI EMAKI AND BAN-DAINAGON EKOTOBA
}

\author{
Hirotaka Oda \\ Center for Chronological Research, Nagoya University. Nagoya Aichi 464-8602, Japan. Corresponding author. \\ Email: oda@nendai.nagoya-u.ac.jp. \\ Kazuomi Ikeda \\ Faculty of Letters, Chuo University, Hachioji, Tokyo 192-0393, Japan.
}

\begin{abstract}
Genji monogatari emaki and Ban-dainagon ekotoba are Japanese national treasures. Although the periods in which they were painted have not been accurately determined, radiocarbon dating cannot be applied to these priceless artifacts because of the destructive nature of ${ }^{14} \mathrm{C}$ dating. In this study, the periods of their origin were determined by ${ }^{14} \mathrm{C}$ dating the kohitsugire calligraphy. Kohitsugire are ancient paper sheets containing graceful calligraphy. They originally were part of ancient manuscripts. Two kohitsugire named Imaki-gire and Kingin-kirihaku-wakanroeishu-gire are written in the same style as Genji monogatari emaki and Ban-dainagon ekotoba. Although Imaki-gire and Kingin-kirihaku-wakanroeishu-gire had been attributed to Asukai Masatsune (AD 1170-1221) on the basis of the kiwamefuda certificates, recent calligraphical and paleographical studies suggest that they are genuine handwritings of Fujiwara no Norinaga (AD 1109-1180?). We applied ${ }^{14} \mathrm{C}$ dating by accelerator mass spectrometry (AMS) to Imaki-gire and Kingin-kirihaku-wakanroeishu-gire. The calibrated ${ }^{14} \mathrm{C}$ ages of both the kohitsugire indicated timing close to the peak of Fujiwara no Norinaga's career as a calligraphist. Based on the associations between the dated texts and the ${ }^{14} \mathrm{C}$ results, it is concluded that the Genji monogatari emaki and Ban-dainagon ekotoba paintings could have been created in the middle of 12th century.
\end{abstract}

\section{INTRODUCTION}

Emakimono is a style of ancient Japanese painting and literature. They are illustrated novels, religious texts, or dictionaries painted on long scrolls of Japanese paper. One of the most famous emakimono is Genji monogatari emaki, which depicts Murasaki Shikibu's novel Tale of Genji through colorful paintings and graceful calligraphy. Although it originally consisted of about 10 scrolls, only 19 painted sheets and 37 calligraphy sheets have survived. Tale of Genji is a novel written $1000 \mathrm{yr}$ ago, in about AD 1008, by Lady Murasaki Shikibu, and is one of the oldest novels in the world. It consists of 54 chapters recounting the gallant life of Hikaru Genji, an imaginary prince, his "son" Kaoru, and his grandson Niounomiya. Therefore, Genji monogatari emaki is also a vital historical resource depicting the culture of the court nobles in the middle Heian period (roughly corresponding to the 10th-11th centuries). Ban-dainagon ekotoba is also a famous emakimono; it deals with the Otenmon no hen incident that took place in AD 866. The incident began with the torching of the Otenmon gate. Although Tomo no Yoshio (Ban-dainagon) accused Minamoto no Yoshio of being the arsonist, Fujiwara no Yoshifusa framed his political rival Tomo no Yoshio for the fires. In the end, Tomo no Yoshio and his son were condemned and sent into exile. Otenmon no hen, which cast a great shadow over the Tomo family, was part of a series of political ploys through which the Fujiwara family eliminated a number of rival families in order to establish their permanent reign.

Genji monogatari emaki, Ban-dainagon ekotoba, and Shigisan-engi emaki are commonly regarded as the 3 greatest and oldest examples of emakimono. They therefore have been designated as Japanese national treasures. However, their periods of origin have not been accurately determined. The paintings of Genji monogatari emaki have been traditionally attributed to Fujiwara no Takayoshi (before AD 1174). The calligraphy of Genji monogatari emaki can be classified into 5 groups on the basis of their styles (Yotsutsuji 2004); therefore, it may be inferred that 5 calligraphists worked on Genji monogatari emaki. Some calligraphy sheets have small rectangular certificates identifying the

(C) 2010 by the Arizona Board of Regents on behalf of the University of Arizona Proceedings of the 20th International Radiocarbon Conference, edited by A J T Jull RADIOCARBON, Vol 52, Nr 2-3, 2010, p 520-525 
writer. According to these certificates, called kiwamefuda, the calligraphy in chapters 36-40 has been attributed to Jakuren (AD 1143?-1202) or Fujiwara no Korefusa (AD 1030-1096), and that in chapters 44 and 45 is attributed to Asukai Masatsune (AD 1170-1221). The calligraphy in Bandainagon ekotoba has also been attributed to Asukai Masatsune. As the dates of the birth and death of those writers differ, not all of these attributions can possibly be accurate. However, paleographical and calligraphical studies, which are independent of kiwamefuda certificates, indicate that the calligraphies in chapters 44 and 45 of Genji monogatari emaki and Ban-dainagon ekotoba are the work of the same calligraphist (Itoh 1939; Komatsu 1961).

The purpose of this study is to determine by radiocarbon dating the periods in which these 2 emakimono were created. However, the method could not be applied directly to these national treasures because of the destructive nature of the analysis. Therefore, we used kohitsugire fragments written by the same calligraphist who wrote the calligraphies of these emakimono as samples for ${ }^{14} \mathrm{C}$ dating.

Kohitsugire are ancient paper fragments or sheets containing graceful calligraphy of Japanese kana syllabary or Chinese characters. They originally comprised pages of ancient manuscripts. Since the tea ceremony achieved great popularity by the end of the 16th century, old manuscripts had been separated as kohitsugire and mounted on hanging scrolls to appreciate their antique calligraphy in the tea houses. Therefore, very few ancient manuscripts written before the 14th century are found in complete form, but a large quantity of kohitsugire fragments have survived.

Kohitsugire calligraphies separated from a single book or series have an identical handwriting, size, and margin; they are referred to by generic names. Kohitsugire sheets named Imaki-gire were separated from the ancient manuscripts of Kokinwakashu (the first of 21 imperial anthologies of waka poems; the original was compiled in AD 905). Kingin-kirihaku-wakanroeishu-gire are kohitsugire works from the ancient manuscripts of Wakanroeishu (an anthology of waka and Chinese poems; the original was compiled around AD 1012 or 1018). The calligraphies of Imaki-gire and Kingin-kirihaku-wakanroeishu-gire are identical to the handwriting in Genji monogatari emaki (chapters 44 and 45) and Ban-dainagon ekotoba (Itoh 1939; Komatsu 1961). They also have kiwamefuda certificates that identify Asukai Masatsune as the writer. According to the certificates, they were written at the peak of his career as a calligraphist, namely, at the end of the 12th century or in the early 13th century. However, paleographical study shows that there are some kohitsugire sheets whose calligraphical styles are incompatible with the descriptions of the kiwamefuda certificates. For example, Chotori-shitae-gire, which has the kiwamefuda certificate of Empress Komyo (AD 701-760), and Genryaku-kohon-manyoshu-gire, which has the kiwamefuda certificate of Prince Munetaka (AD 1242-1274) were both written in the 11th century. Some examples of unreliable kiwamefuda were also found by recent ${ }^{14} \mathrm{C}$ dating of other kohitsugire (Oda et al. 2003, 2007).

With regard to the 8 calligraphical groups attributed to Asukai Masatsune-Imaki-gire, Kingin-kirihaku-wakanroeishu-gire, Hase-gire, Gosenwakashu's manuscript Futaarayamajinjahozohon, and the calligraphies of Genji monogatari emaki (chapters 44 and 45), Ban-dainagon ekotoba, Nenchugyoji emaki (unavailable at present), and Hikohohodeminomikoto emaki (unavailable at present) — calligraphical and paleographical studies concluded a notable theory that they cannot be recognized as works of Asukai Masatsune, but those of Fujiwara no Norinaga (AD 1109-1180?) on the basis of a comparison with their original handwriting (Itoh 1939; Komatsu 1961).

Therefore, we measured the ${ }^{14} \mathrm{C}$ ages of Imaki-gire and Kingin-kirihaku-wakanroeishu-gire to clarify whether they were written by Asukai Masatsune or Fujiwara no Norinaga and determine the periods of the origin of Genji monogatari emaki and Ban-dainagon ekotoba. 


\section{SAMPLES}

The 6 kohitsugire sheets listed in Table 1 were measured by accelerator mass spectrometry (AMS). The Imaki-gire subjected to ${ }^{14} \mathrm{C}$ dating (sample 2-1; Figure 1, left) was a sheet of Japanese paper $(25.7 \times 15.8 \mathrm{~cm})$ made from kozo (mulberry bushes, Broussonetia kazinoki $\times$ Broussonetia papyrifera). It has 2 waka poems recorded in Kokinwakashu Volume 17. The Kingin-kirihaku-wakanroeishu-gire (sample 2-2; Figure 1, right) is a sheet of Japanese paper $(26.5 \times 9.4 \mathrm{~cm})$ made from kozo and ganpi (daphne bushes, Diplomorpha sikokiana), and decorated with small pieces of gold and silver foils. The calligraphy is a part of Wakanroeishu, Volume 1, chapter "Autumn." Besides the kohitsugire attributed to Asukai Masatsune, kohitsugire with known ages were measured as standard samples used to compare the results. Todaiji-gire (sample 1-1) is a fragment from an ancient manuscript entitled Sanpo-ekotoba, written in AD 1120. Ruiju-utaawase-gire (sample 1-2) is from a manuscript of Nijukanbon-ruiju-utaawase, written in AD 1126 or 1127. These 2 kohitsugire precede Imaki-gire and Kingin-kirihaku-wakanroeishu-gire in terms of written age. Kohitsugire sheets corresponding to the time after the peak in Asukai Masatsune's career were also analyzed. Maruyamagire (sample 3-1) belongs to a manuscript of the 8th imperial anthology entitled Shin-kokinwakasyu. It was written in the middle Kamakura period (roughly corresponding to the period from the middle to the late 13th century). Kasuga-gire (sample 3-2) belongs to a manuscript entitled Ononomiyasaneyori-shu and was written in the early Kamakura period (early 13th century).

Table 1 Kohitsugire calligraphies measured by AMS ${ }^{14} \mathrm{C}$ dating.

\begin{tabular}{|c|c|c|}
\hline Sample nr & Name of kohitsugire & Date written \\
\hline \multicolumn{3}{|c|}{ Kohitsugire of known age (written in the AD 1120s) } \\
\hline $1-1$ & Todaiji-gire & AD 1120 \\
\hline $1-2$ & Ruiju-utaawase-gire & AD $1126-1127$ \\
\hline \multicolumn{3}{|c|}{ Kohitsugire attributed to Asukai Masatsune (AD 1170-1221) } \\
\hline $2-1$ & Imaki-gire & \\
\hline $2-2$ & Kingin-kirihaku-wak & \\
\hline \multicolumn{3}{|c|}{ Kohitsugire of known age (written in the 13th century AD) } \\
\hline $3-1$ & Maruyama-gire & Middle or late 13th century \\
\hline $3-2$ & Kasuga-gire & Early 13 th century \\
\hline
\end{tabular}

\section{METHODS}

Japanese paper samples of 12-47 mg were cut from the margins of the kohitsugire. Kohitsugire are commonly mounted on other paper sheets to form a lining. Samples were soaked in distilled water to peel the surface sheet of calligraphy from the mounts. The surface sheets were first washed in distilled water with an ultrasonic cleaner, then treated with $1.2 \mathrm{~N} \mathrm{HCl}$ and $1.2 \mathrm{~N} \mathrm{NaOH}$ solutions on a hot plate (each step was repeated several times for $2-3 \mathrm{hr}$ at $60-70^{\circ} \mathrm{C}$ ). After retreating with $1.2 \mathrm{~N}$ $\mathrm{HCl}$ and rinsing with distilled water (at $60-70{ }^{\circ} \mathrm{C}$ ), the samples were dried in a vacuum desiccator. These samples were combusted using $\mathrm{CuO}$ (at $850{ }^{\circ} \mathrm{C}, 3 \mathrm{hr}$ ) to form $\mathrm{CO}_{2}$, and the purified $\mathrm{CO}_{2}$ was reduced to graphite by $\mathrm{H}_{2}$ in the presence of Fe powder catalyst (at $650{ }^{\circ} \mathrm{C}, 6 \mathrm{hr}$ ) at Paleo Labo Co., Ltd. (Japan). Samples were then measured by AMS (CAMS-500, NEC, USA) at Paleo Labo Co.

\section{RESULTS}

Table 2 gives ${ }^{14} \mathrm{C}$ ages of the kohitsugire calligraphies with 1 - and 2- $\sigma$ error ranges. ${ }^{14} \mathrm{C}$ dates were calibrated to calendar years using the IntCal04 calibration curve (Reimer et al. 2004). In the column containing the calibrated ${ }^{14} \mathrm{C}$ ages, numbers inside parentheses are calibrated values of the mean ${ }^{14} \mathrm{C}$ age, and numbers outside parentheses indicate the error ranges. Calibrated ages are also given in Figure 2. 

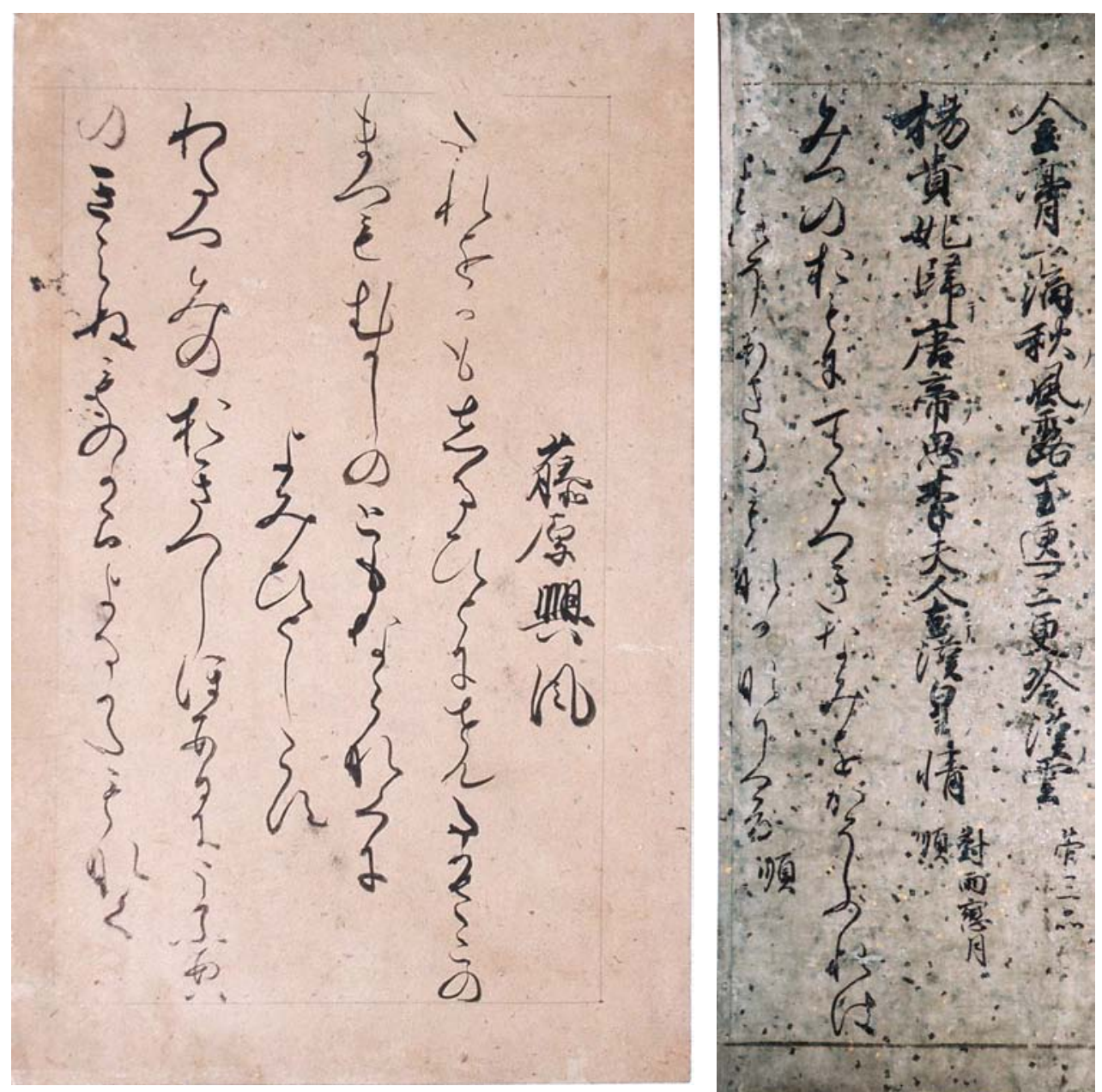

Figure 1 Kohitsugire calligraphies attributed to Asukai Masatsune: Imaki-gire (left) and Kingin-kirihaku-wakanroeishu-gire (right).

Table 2 Results of ${ }^{14} \mathrm{C}$ dating on kohitsugire calligraphies.

\begin{tabular}{lrl}
\hline Sample nr & ${ }^{14} \mathrm{C}$ age $(\mathrm{BP})$ & Calibrated ${ }^{14} \mathrm{C}$ age $(\mathrm{cal}$ AD) \\
\hline $1-1$ & $919 \pm 23(1 \sigma)$ & $1042(1053,1079) 1106 ; 1117$ ( ) 1145; $1145(1153) 1159$ \\
& $\pm 45(2 \sigma)$ & $1030(1053,1079,1153) 1176$ \\
\hline $1-2$ & $946 \pm 22(1 \sigma)$ & $1030(1042) 1052 ; 1081(1107,1117) 1128 ; 1134$ ( ) 1152 \\
& $\pm 43(2 \sigma)$ & $1023(1042,1107,1117) 1158$ \\
\hline $2-1$ & $928 \pm 22(1 \sigma)$ & $1038(1049,1084,1124,1137,1151) 1157$ \\
& $\pm 44(2 \sigma)$ & $1028(1049,1084,1124,1137,1151) 1165$ \\
\hline $2-2$ & $916 \pm 21(1 \sigma)$ & $1044(1054,1078) 1099,1119()) 1142,1147(1153) 1160$ \\
& $\pm 42(2 \sigma)$ & $1032(1054,1078,1153) 1177$ \\
\hline $3-1$ & $791 \pm 22(1 \sigma)$ & $1221(1257) 1265$ \\
& $\pm 43(2 \sigma)$ & $1215(1257) 1274$ \\
\hline $3-2$ & $808 \pm 20(1 \sigma)$ & $1217(1223) 1259$ \\
& $\pm 41(2 \sigma)$ & $1209(1223) 1267$
\end{tabular}




\section{DISCUSSION}

On the basis of the kiwamefuda certificates, Imaki-gire, Kingin-kirihaku-wakanroeishu-gire, the calligraphy in chapters 44 and 45 of Genji monogatari emaki, and that of Ban-dainagon ekotoba had been identified as works of Asukai Masatsune. If kiwamefuda certificates are reliable, Genji monogatari emaki and Ban-dainagon ekotoba were created during the peak of Asukai Masatune's career, i.e. the early 13th century. However, the calibrated ${ }^{14} \mathrm{C}$ ages of 2 kohitsugire attributed to Asukai Masatsune appear to range from the mid-11th to the mid-12th century. For reasons mentioned below, the older ages are not due to the "old wood effect." Japanese paper was made from the branches of kozo, ganpi, and mitsumata (daphne bushes, Edgeworthia chrysantha). Old paper sheets are not generally used for calligraphy because it cannot absorb Indian ink, and it is unsuitable for elegant handwriting. Therefore, the time gap due to tree rings and storage can be estimated at several years. The ${ }^{14} \mathrm{C}$ dating of ancient Japanese documents and sutras of known ages also demonstrated that the calibrated ${ }^{14} \mathrm{C}$ ages correspond to the paleographical ages (Oda et al. 2000, 2003). As shown in Figure 2, ${ }^{14} \mathrm{C}$ ages of kohitsugire of known age (in the 1120s and 13th century) support the proposal that Japanese paper samples are suitable for ${ }^{14} \mathrm{C}$ dating of old calligraphic documents.

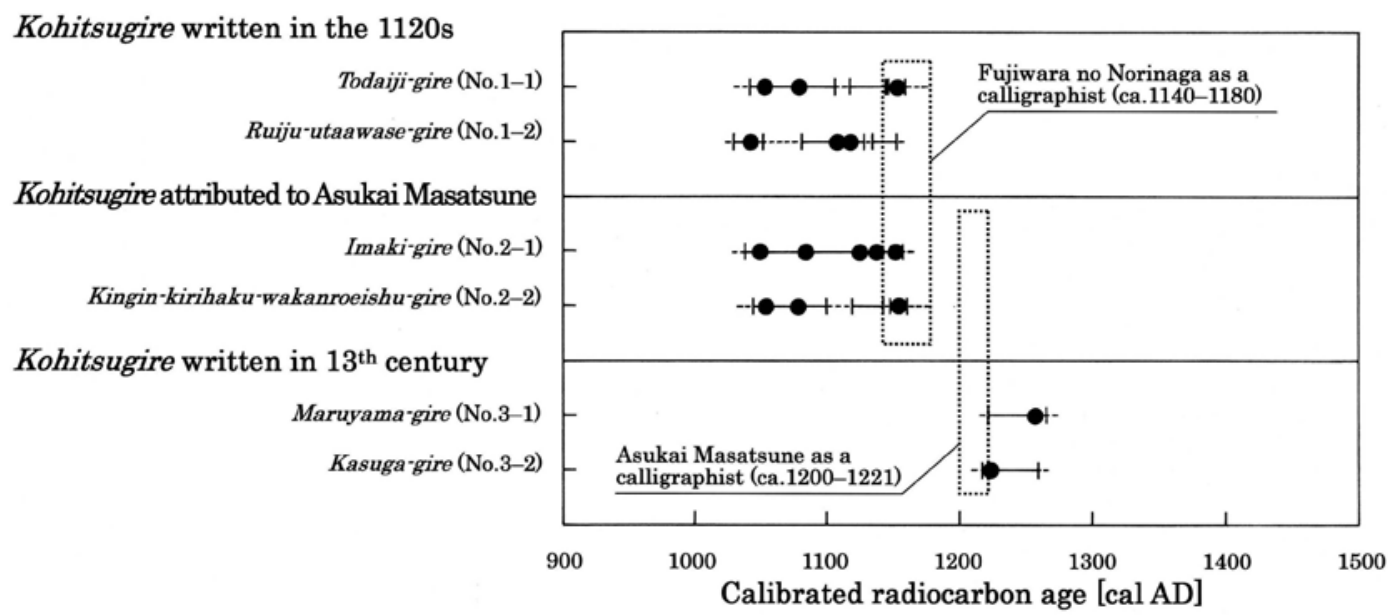

Figure 2 Results of ${ }^{14} \mathrm{C}$ dating on kohitsugire calligraphies. Solid error bars indicate $1 \sigma$; dotted bars, $2 \sigma$.

Therefore, the calibrated ${ }^{14} \mathrm{C}$ ages show that Imaki-gire and Kingin-kirihaku-wakanroeishu-gire were written between the mid-11th and mid-12th century. Although the error ranges are large because the calibration curve from the 11th to the 12th century shows an age plateau, the calibrated ${ }^{14} \mathrm{C}$ ages of Imaki-gire and Kingin-kirihaku-wakanroeishu-gire include periods in which Fujiwara no Norinaga's career flourished as a calligraphist. The results support the previous theory based on calligraphical and paleographical studies. On the basis of the theory that the calligraphies of Genji monogatari emaki (chapters 44 and 45), Ban-dainagon ekotoba, Imaki-gire, and Kingin-kirihakuwakanroeishu-gire were written by the same calligraphist, it is concluded that the creation of Genji monogatari emaki and Ban-dainagon ekotoba dates back to the 12th century. In particular, the date could possibly be reduced to the peak of Fujiwara no Norinaga's career (mid-12th century).

The ages of ancient books and documents are generally deduced from paleographical investigations. However, it is difficult to determine written ages conclusively for kohitsugire with only a few calligraphical lines and uncertain kiwamefuda certificates. If their written ages are determined, kohitsugire fragments might prove to be valuable resources. In this study, the ${ }^{14} \mathrm{C}$ ages of kohitsugire were 
measured and the dated kohitsugire were used to determine the periods of origin of 2 national treasures that could not be subjected to destructive analyses. We therefore consider that ${ }^{14} \mathrm{C}$ dating of kohitsugire will lead to the rediscovery of their value and provide a number of new resources for history, literature, paleography, and bibliography.

\section{ACKNOWLEDGMENTS}

We would like to thank the staff of Paleo Labo Co., Ltd., for their work with regard to ${ }^{14} \mathrm{C}$ dating and helpful discussions. This study was supported in part by a Grant-in Aid for Young Scientists (A) (No. 20680037) from the Japan Society for Promotion of Science.

\section{REFERENCES}

Itoh J. 1939. Fujiwara no Norinaga no hisseki ni tsuite. Gasetsu 32:679-700. In Japanese.

Komatsu S. 1961. Futaarayamajinjahouzouhon Gosenwakasu hissha no suitei to sono hoho. Gosenwakashu: Kohon to Kenkyu, Kenkyu part, Seishin shobo, 1-68. In Japanese.

Oda H, Yoshizawa Y, Nakamura T, Fujita K. 2000. AMS radiocarbon dating of ancient Japanese sutras. $\mathrm{Nu}$ clear Instruments and Methods in Physics Research B 172(1-4):736-40.

Oda H, Masuda T, Niu E, Nakamura T. 2003. AMS radiocarbon dating of ancient Japanese documents of known age. Journal of Radioanalytical and Nuclear Chemistry 255(2):375-9.

Oda H, Ikeda K, Nakamura T. 2007. Radiocarbon age of the kohitsugire calligraphy and the kiwamefuda certif- icate. Nuclear Instruments and Methods in Physics Research B 259(1):374-7.

Reimer PJ, Baillie MGL, Bard E, Bayliss A, Beck JW, Bertrand CJH, Blackwell PG, Buck CE, Burr GS, Cutler KB, Damon PE, Edwards RL, Fairbanks RG, Friedrich M, Guilderson TP, Hogg AG, Hughen KA, Kromer B, McCormac G, Manning S, Bronk Ramsey C, Reimer RW, Remmele S, Southon JR, Stuiver M, Talamo S, Taylor FW, van der Plicht J, Weyhenmeyer CE. 2004. IntCal04 terrestrial radiocarbon age calibration, 0-26 cal kyr BP. Radiocarbon 46(3):1029-58.

Yotsutsuji H. 2004. Genji monogatari emaki. Nippon meihitsusen 46 Genji monogatari emaki: Den Fujiwara no Korefusa hitsu, Den Jakuren hitsu, Den Asukai Masatsune hitsu: Nigensha. p 182-3. In Japanese. 